\title{
Synaptic Modifications in the Medial Prefrontal Cortex in Susceptibility and Resilience to Stress
}

\author{
Minghui Wang, ${ }^{1 \star}$ Zinaida Perova, ${ }^{1,2 *}$ Benjamin R. Arenkiel, ${ }^{3}$ and Bo Li ${ }^{1,2}$ \\ ${ }^{1}$ Cold Spring Harbor Laboratory, Cold Spring Harbor, New York 11724, ${ }^{2}$ Watson School of Biological Sciences, Cold Spring Harbor Laboratory, Cold Spring \\ Harbor, New York 11724, and ${ }^{3}$ Baylor College of Medicine, Houston, Texas 77030
}

When facing stress, most individuals are resilient whereas others are prone to developing mood disorders. The brain mechanisms underlying such divergent behavioral responses remain unclear. Here we used the learned helplessness procedure in mice to examine the role of the medial prefrontal cortex ( $\mathrm{mPFC}$ ), a brain region highly implicated in both clinical and animal models of depression, in adaptive and maladaptive behavioral responses to stress. We found that uncontrollable and inescapable stress induced behavioral statedependent changes in the excitatory synapses onto a subset of mPFC neurons: those that were activated during behavioral responses as indicated by their expression of the activity reporter c-Fos. Whereas synaptic potentiation was linked to learned helplessness, a depression-like behavior, synaptic weakening, was associated with resilience to stress. Notably, enhancing the activity of mPFC neurons using a chemical-genetic method was sufficient to convert the resilient behavior into helplessness. Our results provide direct evidence that mPFC dysfunction is linked to maladaptive behavioral responses to stress, and suggest that enhanced excitatory synaptic drive onto mPFC neurons may underlie the previously reported hyperactivity of this brain region in depression.

Key words: c-Fos; chemical-genetic; depression; excitatory synapses; learned helplessness; mPFC

\section{Introduction}

The prefrontal cortex (PFC) is required for executive control of behavior (Ridderinkhof et al., 2004; McGuire and Botvinick, 2010) and for effective coping with stress (Amat et al., 2005; Sotres-Bayon and Quirk, 2010; Warden et al., 2012). PFC dysfunction has been implicated in mood and anxiety disorders (Mayberg et al., 1999; Etkin, 2010; Milad and Quirk, 2012), which are typically associated with stressful life events. In response to stressors, animals, like humans, adopt either adaptive or maladaptive behavioral strategies. In parallel, stress induces a number of structural and functional changes in neurons of the medial PFC (mPFC), such as dendritic remodeling (Dias-Ferreira et al., 2009), spine loss, and altered synaptic transmission (McEwen, 2007; Goldwater et al., 2009; Yuen et al., 2009). However, the cellular changes in $\mathrm{mPFC}$ that underlie either resilience or susceptibility to stress-induced maladaptive behavioral phenotypes are not well understood. In this study, we used a learned helplessness procedure in mice and exploited the expression of the im-

\footnotetext{
Received Dec. 18, 2013; revised April 17, 2014; accepted April 22, 2014.

Author contributions: B.L. designed research; M.W. and Z.P. performed research; B.R.A. contributed unpublished reagents/analytic tools; M.W., Z.P., and B.L. analyzed data; B.L. wrote the paper.

This work was supported by a Charles A. Dana Fellowship to Z.P., and the National Institutes of Health, the Dana Foundation, National Alliance for Research on Schizophrenia and Depression, and Louis Feil Trust to B.L. We thank L. Van Aelst for critical reading of the manuscript, K. Pradhan and M. Bremer for advice on statistics, and members of the B.L. laboratory for discussions.

The authors declare no competing financial interests.

${ }^{*}$ M.W. and Z.P. contributed equally to this work.

Correspondence should be addressed to Dr. Bo Li, Cold Spring Harbor Laboratory, 1 Bungtown Road, Cold Spring Harbor, NY 11724. E-mail: bli@cshl.edu.

Z. Perova's current address: MRC Laboratory of Molecular Biology, Cambridge CB2 0QH, United Kingdom.

DOI:10.1523/JNEUROSCI.5294-13.2014

Copyright $\odot 2014$ the authors $\quad 0270-6474 / 14 / 347485-08 \$ 15.00 / 0$
}

mediate early gene $c$-fos as a way of tagging activated neurons, to assess stress-induced changes in excitatory synaptic transmission onto mPFC neurons. Furthermore, we directly manipulated mPFC neuronal activity with a chemical-genetic method to probe the relationship between these neurons and behavioral responses to stress.

\section{Materials and Methods}

Animals. Mice were housed under a $12 \mathrm{~h}$ light-dark cycle (9:00 A.M. to 9:00 P.M. light), with food and water freely available. The ROSA-stop flox TRPV1 mice, TRPV1 ${ }^{-1-}$ mice, and FosGFP mice were described previously (Caterina et al., 2000; Reijmers et al., 2007; Arenkiel et al., 2008). All mice were bred onto C57BL/6N (Taconic) genetic background. Male mice of 40-60 d of age were used for all the experiments. The age of mice was matched for each experiment. All procedures involving animals were approved by the Institute Animal Care and Use Committees of Cold Spring Harbor Laboratory.

Immunohistochemistry. Immunohistochemistry experiments were performed following standard procedures. Briefly, mice were deeply anesthetized and transcardially perfused with PBS, followed by perfusion with $4 \%$ PFA. Brains were extracted and further fixed in $4 \%$ PFA overnight at $4^{\circ} \mathrm{C}$ followed by cryoprotection in a 30\% PBS-buffered sucrose solution for $36 \mathrm{~h}$. Coronal sections $(40-50 \mu \mathrm{m})$ were cut using a freezing microtome (SM 2010R, Leica). Sections were first washed in PBS $(3 \times 5$ $\mathrm{min})$ and then incubated in PBST (0.3\% Triton X-100 in PBS) for $30 \mathrm{~min}$ at room temperature, followed by washing with PBS $(3 \times 5 \mathrm{~min})$. Next, sections were blocked in 5\% normal goat serum in PBST for $30 \mathrm{~min}$ at room temperature, followed by incubation with primary antibody overnight at $4^{\circ} \mathrm{C}$. Sections were then washed with PBS $(5 \times 15 \mathrm{~min})$ and incubated with fluorescent secondary antibody at room temperature for $1 \mathrm{~h}$. After washing with PBS $(5 \times 15 \mathrm{~min})$, sections were mounted onto slides with Fluoromount-G (Beckman Coulter). Images were taken using 
a LSM 710 laser-scanning confocal microscope (Carl Zeiss). The primary antibody used was anti-c-fos (rabbit, Santa Cruz Biotechnology, 1:5000).

Behavioral procedures. The learned helplessness procedure in mice has been described previously (Chourbaji et al., 2005a). Mice were first exposed to two induction sessions that were separated by $24 \mathrm{~h}$. Each session consisted of 360 inescapable, uncontrollable electric foot shocks over a $60 \mathrm{~min}$ period. The shock intensity was set at $0.3 \mathrm{~mA}$, the duration of each shock was randomized between 1 and $3 \mathrm{~s}$, and the intershock intervals were randomized between 1 and $15 \mathrm{~s}$.

At $24 \mathrm{~h}$ after the second induction session, mice were subjected to a testing session. The testing, which was fully automated using Graphic State 3.0 software (Coulbourn Instruments), was performed in a shuttle box (14 inches $\times 7$ inches $\times 12$ inches; Coulbourn Instruments) equipped with an electrical grid floor, a door separating the two halves, and photocell detectors. The shuttle box was placed in a sound-attenuating chamber to minimize disturbance by external stimuli. Mice were allowed to explore the shuttle box for $2 \mathrm{~min}$, and behavioral performance was evaluated over 30 trials of escapable foot shocks $(0.3 \mathrm{~mA}$ intensity, $10 \mathrm{~s}$ duration, with intershock intervals of $30 \mathrm{~s})$. Each trial started with a $5 \mathrm{~s}$ cue light, followed by the foot shocks. When an animal shuttled to another compartment of the box during the $5 \mathrm{~s}$ cue light presentation (and therefore before the shock onset), avoidance was scored. If the animal shuttled during the $10 \mathrm{~s}$ shocks (i.e., escaped), escape latency was measured. Failure was recorded if no shuttling was made during the $10 \mathrm{~s}$ shock presentation. Shock was terminated if the animal shuttled to another side of the box (in case of escape) or at the end of the $10 \mathrm{~s}$ shock (in case of failure).

Animals' behavior was classified as being "resilient" or "learned helpless" on the basis of their behavioral parameters in the learned helplessness testing session. A $k$-means $(k=2)$ clustering analysis was applied to a database consisting of 110 Fos GFP mice subjected to the learned helplessness procedure (see Fig. 1A). We used failures and escape latency, the most commonly reported indices of helplessness (Seligman, 1978; Sherman et al., 1982; Caldarone et al., 2000; Vollmayr and Henn, 2001; Ukai et al., 2002; Chourbaji et al., 2005a, b), as parameters for classification. We further performed a linear discriminant analysis on our clustering results, with the number of failures and escape latency as predictor variables, to obtain classification equations for new cases as follows:

$$
\begin{aligned}
& \mathrm{R}=-4.12094+(3.35411 \times \text { escape latency })+(-0.78633 \times \text { failures }) \\
& \mathrm{LH}=-41.23994+(-1.95039 \times \text { escape latency })+(2.38374 \times \text { failures })
\end{aligned}
$$

where the escape latency and the number of failures define the classification scores, R (resilience) and LH (learned helplessness). A mouse is classified as being resilient if $\mathrm{R}>\mathrm{LH}$, or learned helpless if $\mathrm{LH}>\mathrm{R}$. The higher classification score reflects a smaller squared Mahalanobis distance (M-distance) to the centroid of the corresponding group (Chourbaji et al., 2005a).

For the "test-only" group in Figure 2, naive mice were exposed to one learned helplessness testing session described above. For the "brief- shock" group, mice were subjected to 10 times of $1 \mathrm{~s}, 0.3 \mathrm{~mA}$ foot shocks over a 2 min time period.

In addition to the above-mentioned categorical classification of animal behavior, changes in the helplessness behavior, such as those induced by mPFC manipulation (see Fig. 4), were further quantified as changes in an animals' squared M-distance to the centroid of the learned helpless group (Chourbaji et al., 2005a), which gives a continuous (rather than categorical) behavioral index (see Fig. 4).

Stereotaxic surgery. Viral injections were performed using previously described procedures ( $\mathrm{Li}$ et al., 2011, 2013). The following stereotaxic coordinates were used for mPFC: $1.94 \mathrm{~mm}$ anterior from bregma, 0.45 $\mathrm{mm}$ lateral from midline, and $2.4 \mathrm{~mm}$ vertical from the cortical surface. Animals were kept on a heating pad throughout the entire surgical procedure and were brought back to their home cages after $24 \mathrm{~h}$ after surgery recovery and monitoring. Postoperative care included intraperitoneal injection with $0.3-0.5 \mathrm{ml}$ of lactated Ringer's solution and metacam 
A
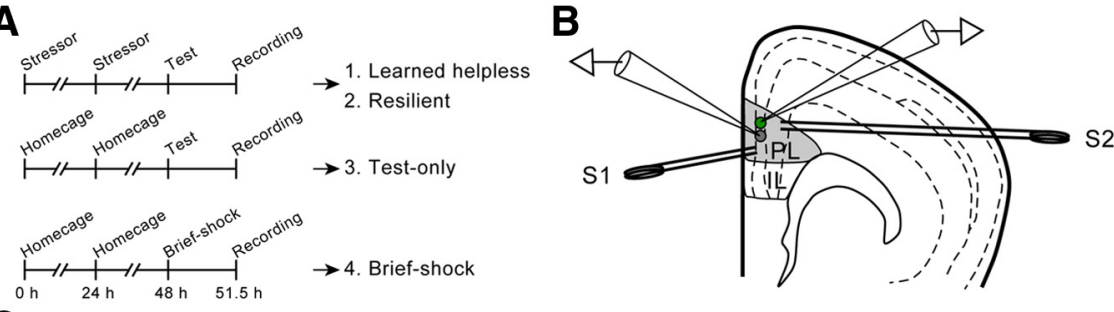

C
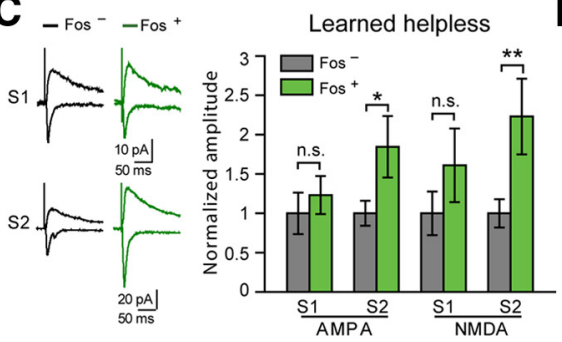

D - Fos $^{-}-$Fos $^{+}$

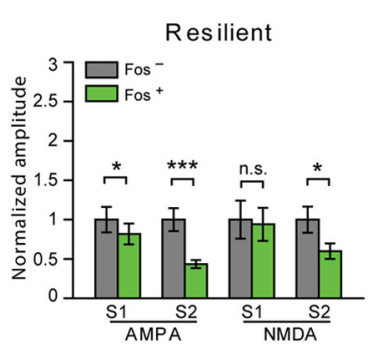

E

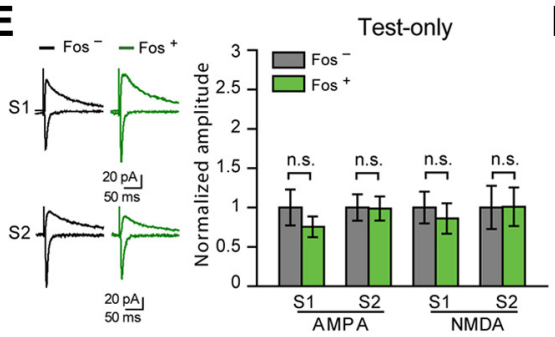

$\mathbf{F}$
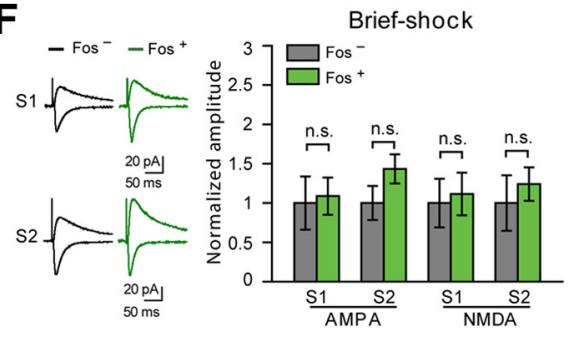

Figure 2. Synaptic modifications in the mPFC associated with susceptibility and resilience to learned helplessness. $A, A$ schematic of the experimental procedure. Top, Mice were subjected to the learned helplessness procedure and were separated into "learned helpless" (1) and "resilient" (2) groups (see Materials and Methods). Middle, Mice were exposed only to the learned helplessness testing session ("test-only") (3). Bottom, Mice were exposed to 10 brief foot shocks ("brief-shock") (4). B, Schematic of the recording configuration. Synaptic responses onto a Fos ${ }^{+}$(green) cell and that onto a Fos ${ }^{-}$(gray) cell in the PL are simultaneously recorded. Synaptic transmission is evoked by two stimulating electrodes: one (S1) placed in layer 2/3 and the other (S2) in layer 5/6. C, Data from the "learned helpless" group. Left, Representative traces of EPSCS, which were recorded from a Fos ${ }^{+}$ neuron (green) and an adjacent Fos ${ }^{-}$neuron (black), and which were evoked by S1 (top) and S2 (bottom). Right, Quantification of AMPAR- and NMDAR-mediated EPSC amplitude, which is normalized to the mean EPSC amplitude of Fos ${ }^{-}$neurons. EPSCs are larger in Fos ${ }^{+}$cells in response to S2 stimulation. D, Data from the "resilient" group. Data presentation is the same as that in $\boldsymbol{C}$. EPSCS onto Fos ${ }^{+}$cells were smaller than those onto Fos ${ }^{-}$cells. $\boldsymbol{E}$, Data from "test-only" group. Data presentation is the same as that in $\boldsymbol{C}$. No significant difference was found. $\boldsymbol{F}$, Data from "brief-shock" group. Data presentation is the same as that in $\boldsymbol{C}$. No significant difference was found. ${ }^{*} p<0.05 .{ }^{* *} p<0.01$. ${ }^{* *} p<0.001$. n.s., Nonsignificant.

(meloxicam, 1-2 mg/kg) for analgesia and anti-inflammatory purposes. The AAV-GFP-IRES-Cre and AAV-GFP viruses were produced by the University of North Carolina Vector Core Facilities. We injected $0.5-0.8$ $\mu$ l of viral solution $\left(\sim 10^{12}\right.$ virus particles/ml) bilaterally into $\mathrm{mPFC}$ and waited $\sim 10-14 \mathrm{~d}$ to allow maximal viral expression.

In vivo chemical-genetic manipulations. To enhance the activity of mPFC neurons, we crossed a knock-in mouse line, ROSA-stop flox $T R P V 1$, in which the excitatory vanilloid receptor TRPV1 is expressed in a Cre-dependent manner (Arenkiel et al., 2008), with the TRPV1 knockout $\left(T R P V 1^{-1-}\right)$ mice (Caterina et al., 2000). In the resulting ROSAstop ${ }^{\text {flox }}$-TRPV1;TRPV1 ${ }^{-1-}$ mice, the endogenous TRPV1 is deleted and the availability of TRPV1 is dependent on Cre expression (Güler et al., 2012). To selectively activate TRPV1 expression in mPFC neurons, we bilaterally injected the mPFC of these mice with an adeno-associated virus expressing the Cre recombinase (AAV-GFP-IRES-Cre). On each testing day, the ROSA-stop flox - TRPV1;TRPV1 ${ }^{-1-}$ mice or control mice were intraperitoneally injected with capsaicin, $5 \mathrm{~min}$ (or $1 \mathrm{~h}$ as indicated) later followed by a learned helplessness testing session. Different doses of capsaicin $(0,10,15$, or $20 \mathrm{mg} / \mathrm{kg})$ were tested on the same mice in different testing sessions, with a $2 \mathrm{~d}$ intersession interval (see Fig. 4C). For examining c-Fos expression, mice were transcardially perfused $1.5 \mathrm{~h}$ after the last capsaicin treatment.

Preparation of acute brain slices and electrophysiology. Mice were anesthetized with isoflurane, decapitated, and their brains quickly removed and chilled in ice-cold dissection buffer as follows: $110.0 \mathrm{~mm}$ choline chloride, $25.0 \mathrm{~mm}$ $\mathrm{NaHCO}_{3}, 1.25 \mathrm{~mm} \mathrm{NaH}_{2} \mathrm{PO}_{4}, 2.5 \mathrm{~mm} \mathrm{KCl}, 0.5$ $\mathrm{mm} \mathrm{CaCl} 2,7.0 \mathrm{~mm} \mathrm{MgCl}_{2}, 25.0 \mathrm{~mm}$ glucose, $11.6 \mathrm{~mm}$ ascorbic acid, and $3.1 \mathrm{~mm}$ pyruvic acid, gassed with $95 \% \mathrm{O}_{2}$ and $5 \% \mathrm{CO}_{2}$. Coronal slices $(300 \mu \mathrm{m})$ containing the $\mathrm{mPFC}$ were cut in dissection buffer using a HM650 Vibrating Microtome (MICROM International) and subsequently transferred to a storage chamber containing ACSF as follows: $118 \mathrm{~mm} \mathrm{NaCl}, 2.5$ $\mathrm{mm} \mathrm{KCl}, 26.2 \mathrm{~mm} \mathrm{NaHCO}, 1 \mathrm{~mm} \mathrm{NaH} \mathrm{PO}_{4}$, $20 \mathrm{~mm}$ glucose, $2 \mathrm{~mm} \mathrm{MgCl}_{2}$, and $2 \mathrm{~mm} \mathrm{CaCl}_{2}$, at $34^{\circ} \mathrm{C}, \mathrm{pH} 7.4$, gassed with $95 \% \mathrm{O}_{2}$ and $5 \%$ $\mathrm{CO}_{2}$. After at least $40 \mathrm{~min}$ recovery time, slices were transferred to room temperature and were constantly perfused with ACSF.

Simultaneous whole-cell patch-clamp recordings from pairs of GFP-positive (thus Fospositive) and GFP-negative (thus Fos-negative) neurons in the prelimbic (PL) region of $\mathrm{mPFC}$ were performed using Multiclamp 700B amplifiers (Molecular Devices). Recordings were under visual guidance using an Olympus BX51 microscope equipped with both transmitted light illumination and epifluorescence illumination. EPSCs of layer 2/3 pyramidal neurons in the PL were evoked by a bipolar stimulating electrode placed either in the superficial layers (layer 2/3) or in the deep layers (layer 5/6) $\sim 0.2$ $\mathrm{mm}$ from the recorded cell bodies in PL. Electrical stimulation was delivered every $5 \mathrm{~s}$ and synaptic responses were low-pass filtered at 1 $\mathrm{kHz}$ and recorded at holding potential of -70 $\mathrm{mV}$ for AMPA receptor (AMPAR)-mediated responses or $40 \mathrm{mV}$ for NMDA receptor (NMDAR)-mediated responses. NMDARmediated responses were quantified as the mean current between 110 and $160 \mathrm{~ms}$ after stimulation onset. Recordings were performed in the ACSF. The internal solution for voltageclamp experiments contained $115 \mathrm{~mm}$ cesium methanesulphonate, $20 \mathrm{~mm} \mathrm{CsCl}, 10 \mathrm{~mm}$ HEPES, $2.5 \mathrm{~mm} \mathrm{MgCl}_{2}, 4 \mathrm{~mm} \mathrm{Na}_{2}$-ATP, $0.4 \mathrm{~mm}$ $\mathrm{Na}_{3} \mathrm{GTP}, 10 \mathrm{~mm}$ Na-phosphocreatine, and 0.6 mM EGTA, pH 7.2. Evoked EPSCs were recorded with picrotoxin $(100 \mu \mathrm{M})$ added to the ACSF. For current-clamp experiments the internal solution consisted of $130 \mathrm{~mm}$ potassium gluconate, $5 \mathrm{~mm} \mathrm{KCl}, 10 \mathrm{~mm}$ HEPES, $2.5 \mathrm{~mm} \mathrm{MgCl}_{2}$, $4 \mathrm{~mm} \mathrm{Na}_{2} \mathrm{ATP}, 0.4 \mathrm{~mm}$ $\mathrm{Na}_{3} \mathrm{GTP}, 10 \mathrm{~mm}$ Na-phophocreatine, and 0.6 mM EGTA, pH 7.2. Electrophysiological data were acquired and analyzed using pCLAMP 10 software (Molecular Devices).

Statistics and data presentation. All statistical tests are indicated where used. All data are presented as mean \pm SEM, unless stated otherwise.

\section{Results}

FosGFP labeling of mPFC neurons activated by the learned helplessness procedure

To investigate the role of $\mathrm{mPFC}$ in mediating behavioral responses to stress, we used mice that have been subjected to an inescapable and unpredictable stressor (Seligman, 1978; Sherman et al., 1982; Maier, 1984; Caldarone et al., 2000; Vollmayr and Henn, 2001; Ukai et al., 2002; Chourbaji et al., 2005a, b; Li et al., 2011) (see Materials and Methods). Approximately 22\% of these mice ( 51 of 228; wild-type mice) displayed learned helplessness, a depression-like phenotype whereby animals show reduced escape from escapable foot shocks (Maier, 1984; Chourbaji et al., 2005a; Li et al., 2011); the rest were resilient. As the age of mice 
ranged from 40 to 60 postnatal days (P40P60) throughout our experiments, we examined the incidence of helplessness in $\mathrm{P} 40-\mathrm{P} 50$ versus $\mathrm{P} 50-\mathrm{P} 60$ mice, which was $22 \%$ ( 26 of 116 ) and $22 \%$ ( 25 of 112), respectively. Therefore, mice in these age groups have similar susceptibility to learned helplessness.

To tag mPFC neurons that are activated in different behavioral states, we exploited the expression of c-Fos, a marker for neuronal activation (Barth, 2007). We took advantage of a FosGFP transgenic mouse line, in which a GFP-labeled c-Fos protein (FosGFP) is expressed under the control of a $c$-fos promoter (Reijmers et al., 2007). Similar to the wild-type mice, $\sim 21 \%$ (23 of 110) of these FosGFP mice were susceptible to helplessness (Fig. 1A). When subjected to the learned helplessness procedure, robust expression of FosGFP was induced in the mPFC of these mice, and the expression profile of FosGFP matched that of endogenous c-Fos (Fig. 1B), consistent with previous findings (Barth, 2007; Reijmers et al., 2007; Cifani et al., 2012). Naive FosGFP mice showed minimal FosGFP expression in the mPFC (data not shown).

\section{Synaptic changes onto mPFC neurons in susceptibility and resilience to stress} The c-Fos ${ }^{+}$mPFC neurons presumably represent a population that is activated during recent behavioral experience. To determine whether these neurons undergo experience-dependent plastic changes, we measured synaptic transmission onto these neurons in acute brain slices prepared from the FosGFP mice subjected to different behavioral procedures (Fig. $2 A$ ). Slices were made at $\sim 3.5 \mathrm{~h}$ after behavioral test (Fig. 2A) when FosGFP is expressed at the highest level (Barth, 2007). We simultaneously recorded pairs of a FosGFP-positive $\left(\mathrm{Fos}^{+}\right.$) and an adjacent FosGFP-negative $\left(\right.$ Fos $^{-}$) pyramidal neuron in layer $2 / 3$ of the PL region of mPFC (Fig. 2B), an area that mediates fear and stress responses (Pendyam et al., 2013). EPSCs were evoked by a stimulating electrode placed either in the superficial (layer 2/3), or deep layers (layer 5/6) (Fig. 2B). This recording strategy permitted direct comparison between synaptic strength onto Fos ${ }^{+}$neurons and that onto Fos ${ }^{-}$neurons.

We found that in mice showing helpless behavior in the learned helplessness procedure, both AMPAR- and NMDARmediated EPSCs evoked by deep layer stimulation were substantially larger in Fos ${ }^{+}$neurons than in Fos ${ }^{-}$neurons (AMPA, $t_{(20)}$ $=-2.15, p<0.05, n=21$ pairs, 7 mice; NMDA, $t_{(20)}=-3.06$, $p<0.01, n=21$ pairs, 7 mice; paired $t$ test) (Figs. $2 A, C$ and $3 A$ ). EPSCs evoked by superficial layer stimulation also tended to be larger in Fos ${ }^{+}$neurons, although this did not reach significance (AMPA, $t_{(21)}=-0.75, p>0.05, n=22$ pairs, 7 mice; NMDA, $t_{(20)}=-1.65, p>0.05, n=21$ pairs, 7 mice; paired $t$ test) (Figs. $2 C$ and $3 A$ ). Unexpectedly, in mice that were resilient to helplessness, EPSCs in Fos ${ }^{+}$neurons were markedly smaller than those in Fos ${ }^{-}$neurons, in particular for EPSCs evoked by deep layer stimulation (superficial layer stimulation: AMPA, $t_{(14)}=2.55, p<$
B Resilient

Learned helpless $\quad$ B
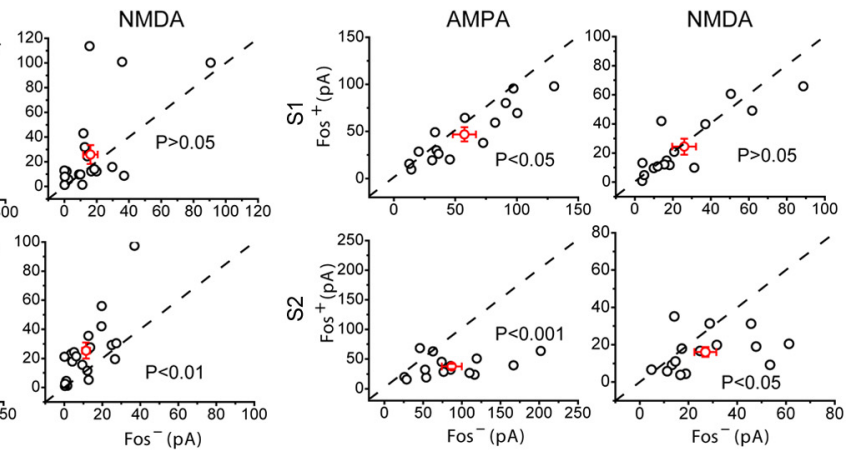

D Brief-shock

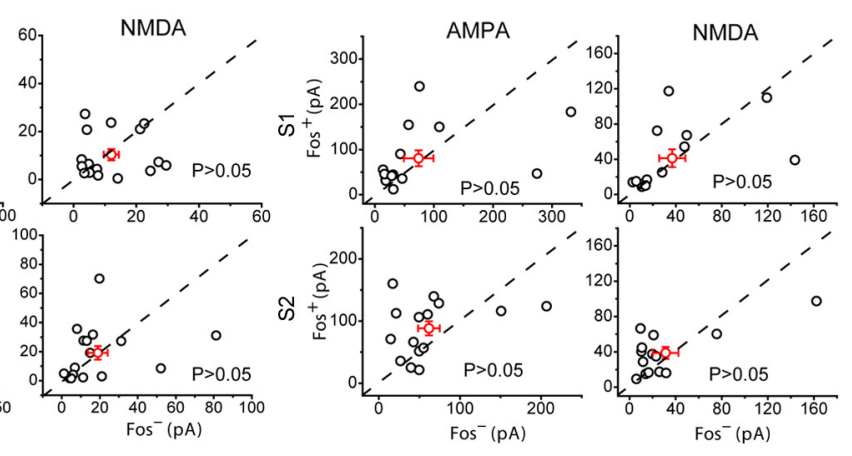
(n) ogy data as those in Figure $2 C-F$, respectively, are presented as scatter plots and in absolute values of EPSC amplitude. Each circle represents amplitudes of EPSCs recorded from a pair of Fos ${ }^{+} / \mathrm{Fos}^{-}$neurons. $\boldsymbol{A}-\boldsymbol{D}$, Left, AMPAR-mediated EPSCs. Right, NMDARmediated EPSCs. Top, EPSCs evoked by S1. Bottom, EPSCs evoked by S2. Red circles represent mean \pm SEM.

0.05, $n=15$ pairs, 8 mice; NMDA, $t_{(14)}=0.49, p>0.05, n=15$ pairs, 8 mice; deep layer stimulation: AMPA, $t_{(14)}=4.14, p<$ $0.001, n=15$ pairs, 8 mice; NMDA, $t_{(14)}=2.48, p<0.05, n=15$ pairs, 8 mice; paired $t$ test) (Figs. $2 A, D$ and $3 B$ ). There was no obvious difference between Fos $^{+}$and Fos $^{-}$neurons in the strength of excitatory synaptic inputs in mice treated with milder stressors, such as one learned helplessness testing session that was composed of 30 escapable foot shocks (superficial layer stimulation: AMPA, $t_{(16)}=1.68, p>0.05, n=17$ pairs, 6 mice; NMDA, $t_{(16)}=0.51, p>0.05, n=16$ pairs, 6 mice; deep layer stimulation: AMPA, $t_{(16)}=0.07, p>0.05, n=17$ pairs, 6 mice; NMDA, $t_{(15)}=$ $-0.03, p>0.05, n=16$ pairs, 6 mice; paired $t$ test) ("test-only"; Figs. $2 A, E$ and $3 C$ ), or 10 inescapable foot shocks (superficial layer stimulation: AMPA, $t_{(14)}=-0.27, p>0.05, n=15$ pairs, 7 mice; NMDA, $t_{(13)}=-0.4, p>0.05, n=14$ pairs, 7 mice; deep layer stimulation: AMPA, $t_{(14)}=-1.8, p>0.05, n=15$ pairs, 7 mice; NMDA, $t_{(13)}=-0.95, p>0.05, n=14$ pairs, 7 mice; paired $t$ test) ("brief-shock"; Figs. $2 A, F$ and $3 D$ ) (see Materials and Methods). Together, these results indicate that helplessness is associated with enhanced, whereas resilience is associated with reduced, excitatory synaptic transmission onto mPFC neurons that are actively recruited during behavioral responses. Furthermore, prior exposure to high levels of stress appears to be necessary for the induction of these changes.

\section{Enhancing mPFC neuronal activity converts resilience into helplessness}

The enhanced excitatory synaptic transmission onto MPFC neurons in helpless mice may drive aberrantly elevated neuronal activity. In contrast, the weakened synaptic transmission in resilient 

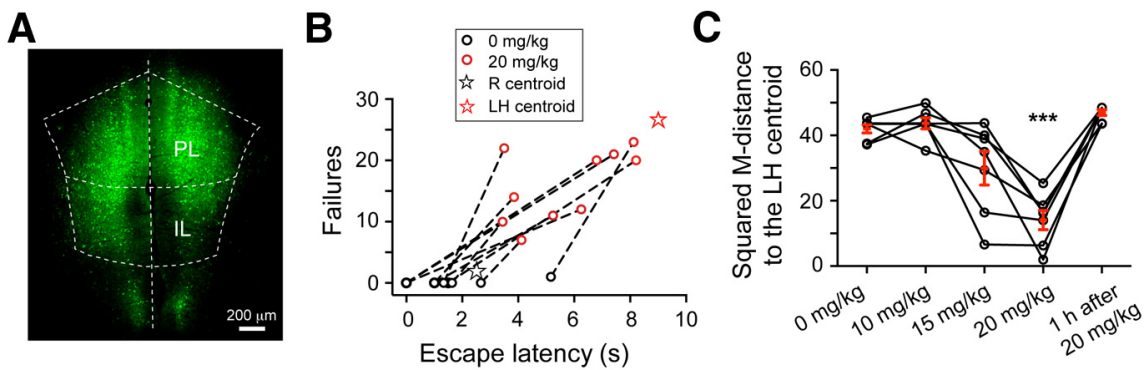

D
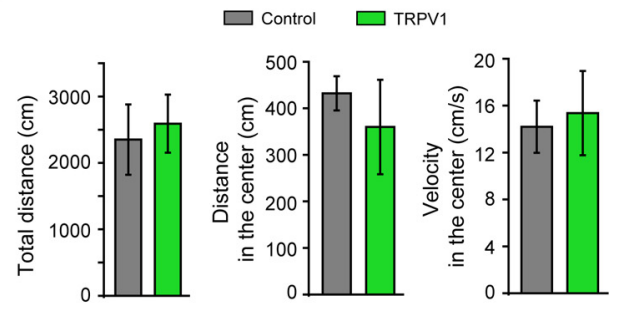

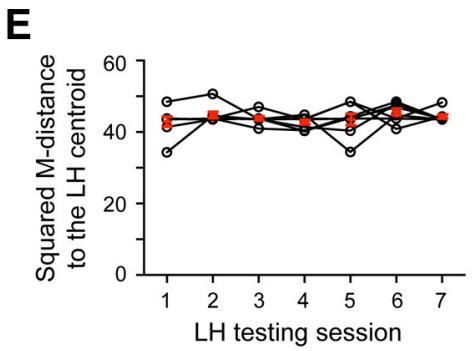

Figure 4. Chemical-genetic activation of mPFC neurons in ROSA-stop flox $-T R P V 1 ; T_{R P V 1}{ }^{-1-}$ mice converts resilience to helplessness-like behavior. $A$, Representative image of the mPFC of a ROSA-stop ${ }^{\text {flox }}$-TRPV1;TRPV1 ${ }^{-1-}$ mouse with bilateral injections of AAV-GFP-IRES-Cre to activate TRPV expression. B, Capsaicin treatment $(20 \mathrm{mg} / \mathrm{kg}$, i.p.) of the injected mice markedly increased both the number of failures and escape latency in the learned helplessness testing session. These behavioral parameters for each mouse are represented by a pair of circles, with the black and red circles indicating parameters measured in the absence and presence, respectively, of capsaicin treatment. Dashed line connects circles representing the same mouse. Compared with the black circles, the red circles are closer to the LH centroid (red star, reproduced from Fig. $1 A$ for visual inspection). C, Behavioral effect of capsaicin treatment, quantified as the squared M-distance to the LH centroid (Fig. 1A; see Materials and Methods), was dose-dependent and reversible. The same mice were tested for learned helplessness at 5 min after each of the capsaicin treatment at the indicated dose, and also at $1 \mathrm{~h}$ for $20 \mathrm{mg} / \mathrm{kg}$ only. D, Chemical- genetic activation of mPFC neurons does not affect motor activity in an open field test. The "TRPV1" mice are the same ROSA-stop ${ }^{\text {flox }}$-TRPV1; TRPV1 ${ }^{-1-}$ mice (in which the mPFC were injected with AAV-GFP-IRES-Cre) used in $\boldsymbol{B}$ and $\boldsymbol{C}$. The "Control" mice are ROSA-stof ${ }^{\text {flox }}$-TRPV1;TRPV1 ${ }^{-1-}$ mice without viral injection. At 5 min after treatment with capsaicin, mice were tested in an open field test. The total distance traveled (left), distance traveled in the center (middle), and velocity in the center (right) of the arena were measured. Activation of $\mathrm{mPFC}$ neurons by capsaicin did not significantly affect these parameters. $\boldsymbol{E}$, Resilient mice were repeatedly tested in the learned helplessness testing sessions, with a $2 \mathrm{~d}$ intersession interval. Behavioral responses are quantified as in $\boldsymbol{C}$. The resilient behavior did not change with repeated testing. ${ }^{* * *} p<0.001$.
A

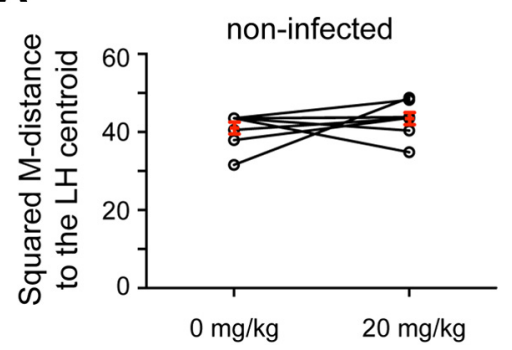

B

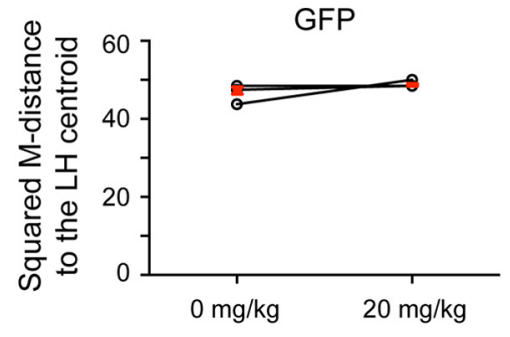

Figure 5. Administration of capsaicin alone does not affect the behavior of the ROSA-stop ${ }^{\text {flox }}$-TRPV1;TRPV1 ${ }^{-1-}$ mice. $\boldsymbol{A}_{\text {, }}$ Behavioral responses were quantified as in Figure 4C. Capsaicin treatment did not change the behavioral responses of ROSAstop $^{\text {flox }}$-TRPV1;TRPV1 ${ }^{-1-}$ mice that did not receive virus injection. Each circle represents one mouse; some of the circles are overlapping. $\boldsymbol{B}$, Same as $\boldsymbol{A}$, except that the ROSA-stop ${ }^{\text {flox }}$-TRPV1;TRPV1 ${ }^{-1-}$ mice were injected with an AAV-GFP into the mPFC. Some of the circles are overlapping.

mice could dampen the activity levels of mPFC neurons in response to excitatory inputs and thus may represent an active adaptive process that prevents $\mathrm{mPFC}$ hyperactivity. To investigate the relationship between $\mathrm{mPFC}$ neuronal activity and the expression of helpless behavior, we artificially enhanced the activity of mPFC neurons using a chemical-genetic approach. For this purpose, we crossed the ROSA-stop ${ }^{\text {flox }}$-TRPV1 mice, in which the excitatory vanilloid receptor TRPV1 is expressed in a Credependent manner (Arenkiel et al., 2008), with the TRPV1 knock-out $\left(T R P V 1^{-1-}\right)$ mice (Caterina et al., 2000). In the re- sulting ROSA-stop ${ }^{\text {flox }}$-TRPV1;TRPV1 ${ }^{-1-}$ mice, the endogenous TRPV1 is deleted, and the availability of TRPV1 is dependent on Cre expression (Güler et al., 2012). When subjected to the learned helplessness procedure, $\sim 25 \%$ (3 of 12) of these mice became helpless, an incidence that is similar to that of the wild-type and FosGFP mice (Fig. 1A).

To selectively activate TRPV1 expression in $\mathrm{mPFC}$ neurons, we bilaterally injected the mPFC of the ROSA-stop ${ }^{\text {flox }}$ TRPV1;TRPV1 ${ }^{-1-}$ mice with an adenoassociated virus expressing the Cre recombinase (AAV-GFP-IRES-Cre) (Fig. $4 A)$. We then subjected these mice to the learned helplessness procedure. The resilient mice were selected and treated with capsaicin, the ligand of TRPV1, to activate the mPFC neurons. Notably, treatment of these mice with capsaicin induced marked increase in both the number of failures and latency to escape foot shocks $\left(T^{2}=\right.$ 40.54, $F_{(2,21)}=19.35, p<0.001, n=10$ mice; multivariate paired Hotelling's $T^{2}$ test), which are parameters defining learned helplessness (Chourbaji et al., 2005a) (Fig. 4B). Indeed, 6 of 10 of these resilient mice reached criteria for helplessness when tested after capsaicin administration (see Materials and Methods). The effect of capsaicin on helpless behavior was dose-dependent and reversible $\left(F_{(1.85,11.10)}=23.78 ; p<0.001, n=7\right.$ mice, repeated-measures ANOVA followed by Dunnett's multiple-comparisons test, comparing each group with the $0 \mathrm{mg} / \mathrm{kg}$ group) (Fig. 4C). In contrast, capsaicin did not affect motor activity of these mice in an open field test (total distance, $t_{(4)}=$ $-0.347, p>0.05$; distance in the center, $t_{(4)}=0.67, p>0.05$; velocity in the center $t_{(4)}=-0.27, p>0.05$; $t$ test; $n=3$ mice for both groups) (Fig. $4 D$ ). This result is remarkable, as normally resilient mice (including the ROSA-stop ${ }^{\text {flox }}-T R P V 1$; TRPV1 ${ }^{-1-}$ mice) do not become helpless even after repeated learned helplessness testing sessions $\left(F_{(2.54,17.75)}=0.91, p>0.05\right.$, $n=8$ mice, repeated-measures ANOVA) (Fig. 4E).

Capsaicin treatment did not change the resilient behavior of control ROSAstop ${ }^{\text {flox }}$-TRPV1;TRPV1 $1^{-1-}$ mice, which did not receive viral injection $\left(t_{(7)}=-1.07, p>0.05, n=8\right.$ mice, paired $t$ test) (Fig. $5 A$ ) or were injected in $\mathrm{mPFC}$ with a control virus (AAV-GFP) $\left(t_{(4)}=\right.$ $0.38, p>0.05, n=5$ mice, paired $t$ test) (Fig. $5 B$ ), indicating TRPV1 expression in $\mathrm{mPFC}$ is required for capsaicin's action. Consistent with this result, capsaicin administration induced robust c-Fos expression in both the PL and infralimbic (IL) areas of mPFC where TRPV1 expression was selectively activated, but not in the mPFC of mice that were devoid of TRPV1 1 PL, $F_{(3,14)}=4.8$, $p<0.05$; IL, $F_{(3,14)}=6.1, p<0.05 ; n=8,5$, and 5 mice for the 
TRPV1 group, noninfected group, and GFP group, respectively; one-way ANOVA followed by Tukey test) (Fig. 6A,B). Furthermore, capsaicin enhanced the firing of TRPV1-positive, but not TRPV1-negative, mPFC neurons (Fig. 6C). Together, these data indicate that enhancement of neuronal activity in the mPFC converts resilience into a helplessness-like phenotype.

\section{Discussion}

The learned helplessness procedure, which has been widely used to mimic situations that can cause depression or anxiety disorders in humans (Maier, 1984; Chourbaji et al., 2005a; Henn and Vollmayr, 2005; Maier and Watkins, 2005; Li et al., 2011), induces opposing synaptic changes in the mPFC that are specifically associated with the stress-induced behavioral outcomes. On one hand, excitatory synapses onto a population of mPFC neurons are strengthened in mice showing learned helplessness, a result that suggests a potential cellular mechanism underlying $\mathrm{mPFC}$ hyperactivity observed in clinical depression (Mayberg et al., 1999, 2005; Etkin, 2010; Holtzheimer and Mayberg, 2011). On the other hand, excitatory synapses onto mPFC neurons are weakened in mice that are resilient to helplessness, a change that may represent an active cellular adaptive process to dampen mPFC hyperactivity. These results are consistent with the finding that deep brain stimulation, which can inhibit neuronal activity in the targeted brain area (Mayberg et al., 2005; Holtzheimer and Mayberg, 2011), in mPFC is effective in alleviating symptoms in depressed humans or rodent models of depression (Covington et al., 2010; Hamani et al., 2010; Warden et al., 2012).

Although the subgenual cingulate cortex (Brodmann's area 25; Cg25), an area thought to be homologous to the mPFC in rodents, has been consistently found to be hyperactive in mood disorders (Ressler and Mayberg, 2007; Drevets et al., 2008; Hamani et al., 2011), previous studies also reported reductions in measures of excitatory drive in the PFC in rodents subjected to chronic stress procedures (Dias-Ferreira et al., 2009; Goldwater et al., 2009) or in patients with major depression (Price and Drevets, 2012). This impairment in excitatory drive, which is typically observed in animals subjected to several weeks of stress or in patients at the endpoint of disease (e.g., in postmortem studies) is likely the result of prolonged stress or disease process. The learned helplessness procedure that we used is relatively short ( 3 d); therefore, the neural changes we observed may underlie a stress-related behavioral state different from that seen in chronically stressed animals or at the endpoint of depression.

In addition to Cg25 hyperactivity, other PFC areas, such as the lateral prefrontal cortices, often show hypoactivity in neuroimaging studies on depression patients (Northoff et al., 2011; Kinou et al., 2013; Rive et al., 2013), consistent with evidence that different PFC areas serve different functions and have different roles in mood disorders (Koenigs et al., 2008; Northoff et al., 2011).
The ROSA-stop ${ }^{\text {flox }}$-TRPV1;TRPV1 ${ }^{-1-}$ mice used in this study have been characterized previously (Güler et al., 2012). They were bred onto the TRPV1 ${ }^{-1-}$ genetic background, which is associated with impaired noxious temperature detection and decreased inflammation-induced thermal hyperalgesia resulting from the loss of TRPV1 channel (Caterina et al., 2000; Birder et al., 2002). However, these mice have normal responses to noxious mechanical stimuli (Caterina et al., 2000; Güler et al., 2012). We observed that these mice had normal behavioral reactions to electrical footshocks and similar vulnerability to helplessness compared with wild-type mice, indicating they have relatively intact sensation of electrical shock. Importantly, even if they had subtle impairment in sensing electrical shocks, which would render resilience, we were able to drive helplessness in these mice by activating $\mathrm{mPFC}$ neurons, demonstrating the robustness of this result.

Previous studies have shown that optogenetic activation of $\mathrm{mPFC}$ neurons in rodents induces depression-like effects (Yizhar et al., 2011; Warden et al., 2012), although an antidepressant-like effect has also been reported (Covington et al., 2010). This discrepancy could be caused by variations in the stimulation of mPFC subpopulations or specific circuits across different studies. In this regard, recent studies implicate several mPFC circuits in the generation of depression- or resilience-like behaviors in rodents. For example, selective stimulation of the mPFC-lateral habenula (Amat et al., 2001; Li et al., 2011; Warden et al., 2012) or the mPFC-amygdala pathway (Martinez et al., 2013; Moscarello and LeDoux, 2013) induces depression-like responses, whereas 
selective stimulation of the mPFC-dorsal raphe pathway promotes resilience (Warden et al., 2012). Our approach induces an overall enhancement of mPFC activity that readily converts resilience to helplessness, an effect that is likely predominated by the mPFC-lateral habenula and/or mPFC-amygdala pathways. This result provides further evidence that hyperactivity of $\mathrm{mPFC}$ is causally linked to the stress-induced behavioral maladaptation. The precise mechanisms by which mPFC interacts with downstream targets and orchestrates different behavioral responses to stress, in particular resilience to stress, warrant further investigation.

\section{References}

Amat J, Sparks PD, Matus-Amat P, Griggs J, Watkins LR, Maier SF (2001) The role of the habenular complex in the elevation of dorsal raphe nucleus serotonin and the changes in the behavioral responses produced by uncontrollable stress. Brain Res 917:118-126. CrossRef Medline

Amat J, Baratta MV, Paul E, Bland ST, Watkins LR, Maier SF (2005) Medial prefrontal cortex determines how stressor controllability affects behavior and dorsal raphe nucleus. Nat Neurosci 8:365-371. CrossRef Medline

Arenkiel BR, Klein ME, Davison IG, Katz LC, Ehlers MD (2008) Genetic control of neuronal activity in mice conditionally expressing TRPV1. Nat Methods 5:299-302. CrossRef Medline

Barth AL (2007) Visualizing circuits and systems using transgenic reporters of neural activity. Curr Opin Neurobiol 17:567-571. CrossRef Medline

Birder LA, Nakamura Y, Kiss S, Nealen ML, Barrick S, Kanai AJ, Wang E, Ruiz G, De Groat WC, Apodaca G, Watkins S, Caterina MJ (2002) Altered urinary bladder function in mice lacking the vanilloid receptor TRPV1. Nat Neurosci 5:856-860. CrossRef Medline

Caldarone BJ, George TP, Zachariou V, Picciotto MR (2000) Gender differences in learned helplessness behavior are influenced by genetic background. Pharmacol Biochem Behav 66:811-817. CrossRef Medline

Caterina MJ, Leffler A, Malmberg AB, Martin WJ, Trafton J, Petersen-Zeitz KR, Koltzenburg M, Basbaum AI, Julius D (2000) Impaired nociception and pain sensation in mice lacking the capsaicin receptor. Science 288: 306-313. CrossRef Medline

Chourbaji S, Zacher C, Sanchis-Segura C, Dormann C, Vollmayr B, Gass P (2005a) Learned helplessness: validity and reliability of depressive-like states in mice. Brain Res Brain Res Protoc 16:70-78. CrossRef Medline

Chourbaji S, Zacher C, Sanchis-Segura C, Spanagel R, Gass P (2005b) Social and structural housing conditions influence the development of a depressive-like phenotype in the learned helplessness paradigm in male mice. Behav Brain Res 164:100-106. CrossRef Medline

Cifani C, Koya E, Navarre BM, Calu DJ, Baumann MH, Marchant NJ, Liu QR, Khuc T, Pickel J, Lupica CR, Shaham Y, Hope BT (2012) Medial prefrontal cortex neuronal activation and synaptic alterations after stressinduced reinstatement of palatable food seeking: a study using c-fos-GFP transgenic female rats. J Neurosci 32:8480-8490. CrossRef Medline

Covington HE 3rd, Lobo MK, Maze I, Vialou V, Hyman JM, Zaman S, LaPlant Q, Mouzon E, Ghose S, Tamminga CA, Neve RL, Deisseroth K, Nestler EJ (2010) Antidepressant effect of optogenetic stimulation of the medial prefrontal cortex. J Neurosci 30:16082-16090. CrossRef Medline

Dias-Ferreira E, Sousa JC, Melo I, Morgado P, Mesquita AR, Cerqueira JJ, Costa RM, Sousa N (2009) Chronic stress causes frontostriatal reorganization and affects decision-making. Science 325:621-625. CrossRef Medline

Drevets WC, Savitz J, Trimble M (2008) The subgenual anterior cingulate cortex in mood disorders. CNS Spectr 13:663-681. Medline

Etkin A (2010) Functional neuroanatomy of anxiety: a neural circuit perspective. Curr Top Behav Neurosci 2:251-277. Medline

Goldwater DS, Pavlides C, Hunter RG, Bloss EB, Hof PR, McEwen BS, Morrison JH (2009) Structural and functional alterations to rat medial prefrontal cortex following chronic restraint stress and recovery. Neuroscience 164:798-808. CrossRef Medline

Güler AD, Rainwater A, Parker JG, Jones GL, Argilli E, Arenkiel BR, Ehlers MD, Bonci A, Zweifel LS, Palmiter RD (2012) Transient activation of specific neurons in mice by selective expression of the capsaicin receptor. Nat Commun 3:746. CrossRef Medline

Hamani C, Diwan M, Macedo CE, Brandão ML, Shumake J, Gonzalez-Lima F, Raymond R, Lozano AM, Fletcher PJ, Nobrega JN (2010) Antidepressantlike effects of medial prefrontal cortex deep brain stimulation in rats. Biol Psychiatry 67:117-124. CrossRef Medline
Hamani C, Mayberg H, Stone S, Laxton A, Haber S, Lozano AM (2011) The subcallosal cingulate gyrus in the context of major depression. Biol Psychiatry 69:301-308. CrossRef Medline

Henn FA, Vollmayr B (2005) Stress models of depression: forming genetically vulnerable strains. Neurosci Biobehav Rev 29:799-804. CrossRef Medline

Holtzheimer PE, Mayberg HS (2011) Deep brain stimulation for psychiatric disorders. Annu Rev Neurosci 34:289-307. CrossRef Medline

Kinou M, Takizawa R, Marumo K, Kawasaki S, Kawakubo Y, Fukuda M, Kasai K (2013) Differential spatiotemporal characteristics of the prefrontal hemodynamic response and their association with functional impairment in schizophrenia and major depression. Schizophr Res 150: 459-467. CrossRef Medline

Koenigs M, Huey ED, Calamia M, Raymont V, Tranel D, Grafman J (2008) Distinct regions of prefrontal cortex mediate resistance and vulnerability to depression. J Neurosci 28:12341-12348. CrossRef Medline

Li B, Piriz J, Mirrione M, Chung C, Proulx CD, Schulz D, Henn F, Malinow R (2011) Synaptic potentiation onto habenula neurons in the learned helplessness model of depression. Nature 470:535-539. CrossRef Medline

Li H, Penzo MA, Taniguchi H, Kopec CD, Huang ZJ, Li B (2013) Experience-dependent modification of a central amygdala fear circuit. Nat Neurosci 16:332-339. CrossRef Medline

Maier SF (1984) Learned helplessness and animal models of depression. Prog Neuropsychopharmacol Biol Psychiatry 8:435-446. CrossRef Medline

Maier SF, Watkins LR (2005) Stressor controllability and learned helplessness: the roles of the dorsal raphe nucleus, serotonin, and corticotropin-releasing factor. Neurosci Biobehav Rev 29:829-841. CrossRef Medline

Martinez RC, Gupta N, Lázaro-Muñoz G, Sears RM, Kim S, Moscarello JM, LeDoux JE, Cain CK (2013) Active vs. reactive threat responding is associated with differential c-Fos expression in specific regions of amygdala and prefrontal cortex. Learn Mem 20:446-452. CrossRef Medline

Mayberg HS, Liotti M, Brannan SK, McGinnis S, Mahurin RK, Jerabek PA, Silva JA, Tekell JL, Martin CC, Lancaster JL, Fox PT (1999) Reciprocal limbic-cortical function and negative mood: converging PET findings in depression and normal sadness. J Psychiatry 156:675-682. Medline

Mayberg HS, Lozano AM, Voon V, McNeely HE, Seminowicz D, Hamani C, Schwalb JM, Kennedy SH (2005) Deep brain stimulation for treatmentresistant depression. Neuron 45:651-660. CrossRef Medline

McEwen BS (2007) Physiology and neurobiology of stress and adaptation: central role of the brain. Physiol Rev 87:873-904. CrossRef Medline

McGuire JT, Botvinick MM (2010) Prefrontal cortex, cognitive control, and the registration of decision costs. Proc Natl Acad Sci U S A 107:79227926. CrossRef Medline

Milad MR, Quirk GJ (2012) Fear extinction as a model for translational neuroscience: ten years of progress. Annu Rev Psychol 63:129-151. CrossRef Medline

Moscarello JM, LeDoux JE (2013) Active avoidance learning requires prefrontal suppression of amygdala-mediated defensive reactions. J Neurosci 33:3815-3823. CrossRef Medline

Northoff G, Wiebking C, Feinberg T, Panksepp J (2011) The 'resting-state hypothesis' of major depressive disorder: a translational subcortical-cortical framework for a system disorder. Neurosci Biobehav Rev 35:1929_ 1945. CrossRef Medline

Pendyam S, Bravo-Rivera C, Burgos-Robles A, Sotres-Bayon F, Quirk GJ, Nair SS (2013) Fear signaling in the prelimbic-amygdala circuit: a computational modeling and recording study. J Neurophysiol 110:844-861. CrossRef Medline

Price JL, Drevets WC (2012) Neural circuits underlying the pathophysiology of mood disorders. Trends Cogn Sci 16:61-71. CrossRef Medline

Reijmers LG, Perkins BL, Matsuo N, Mayford M (2007) Localization of a stable neural correlate of associative memory. Science 317:1230-1233. CrossRef Medline

Ressler KJ, Mayberg HS (2007) Targeting abnormal neural circuits in mood and anxiety disorders: from the laboratory to the clinic. Nat Neurosci 10:1116-1124. CrossRef Medline

Ridderinkhof KR, van den Wildenberg WP, Segalowitz SJ, Carter CS (2004) Neurocognitive mechanisms of cognitive control: the role of prefrontal cortex in action selection, response inhibition, performance monitoring, and reward-based learning. Brain Cogn 56:129140. CrossRef Medline 
Rive MM, van Rooijen G, Veltman DJ, Phillips ML, Schene AH, Ruhé HG (2013) Neural correlates of dysfunctional emotion regulation in major depressive disorder: a systematic review of neuroimaging studies. Neurosci Biobehav Rev 37:2529-2553. CrossRef Medline

Seligman ME (1978) Learned helplessness as a model of depression: comment and integration. J Abnorm Psychol 87:165-179. CrossRef Medline

Sherman AD, Sacquitne JL, Petty F (1982) Specificity of the learned helplessness model of depression. Pharmacol Biochem Behav 16:449-454. CrossRef Medline

Sotres-Bayon F, Quirk GJ (2010) Prefrontal control of fear: more than just extinction. Curr Opin Neurobiol 20:231-235. CrossRef Medline

Ukai M, Suzuki M, Mamiya T (2002) Effects of U-50488H, a kappa-opioid receptor agonist, on the learned helplessness model of depression in mice. J Neural Transm 109:1221-1225. CrossRef Medline

Vollmayr B, Henn FA (2001) Learned helplessness in the rat: improvements in validity and reliability. Brain Res Brain Res Protoc 8:1-7. CrossRef Medline

Warden MR, Selimbeyoglu A, Mirzabekov JJ, Lo M, Thompson KR, Kim SY, Adhikari A, Tye KM, Frank LM, Deisseroth K (2012) A prefrontal cortex-brainstem neuronal projection that controls response to behavioural challenge. Nature 492:428-432. CrossRef Medline

Yizhar O, Fenno LE, Prigge M, Schneider F, Davidson TJ, O’Shea DJ, Sohal VS, Goshen I, Finkelstein J, Paz JT, Stehfest K, Fudim R, Ramakrishnan C, Huguenard JR, Hegemann P, Deisseroth K (2011) Neocortical excitation/inhibition balance in information processing and social dysfunction. Nature 477:171-178. CrossRef Medline

Yuen EY, Liu W, Karatsoreos IN, Feng J, McEwen BS, Yan Z (2009) Acute stress enhances glutamatergic transmission in prefrontal cortex and facilitates working memory. Proc Natl Acad Sci U S A 106:14075-14079. CrossRef Medline 